Abstracta Iranica Abstracta Iranica

Revue bibliographique pour le domaine irano-aryen

Volume 32-33 | 2013

Comptes rendus des publications de 2009-2010

\title{
Mawlānā Nūr al-Dīn 'Abd al-Raḥmān Jāmī. Tuhfat al-aḥrār. Éd. et commentaire Bītā Nūrīyān
}

Anna Livia Beelaert

\section{OpenEdition}

1 Journals

\section{Édition électronique}

URL : http://journals.openedition.org/abstractairanica/40958

DOI : 10.4000/abstractairanica.40958

ISSN : 1961-960X

Éditeur :

CNRS (UMR 7528 Mondes iraniens et indiens), Éditions de l'IFRI

\section{Édition imprimée}

Date de publication : 1 décembre 2013

ISSN : 0240-8910

\section{Référence électronique}

Anna Livia Beelaert, « Mawlānā Nūr al-Dīn 'Abd al-Raḥmān Jāmī. Tuḥfat al-aḥrār. Éd. et commentaire Bìtā Nūrīyān », Abstracta Iranica [En ligne], Volume 32-33 | 2013, document 427, mis en ligne le 01 juillet 2016, consulté le 03 octobre 2020. URL : http://journals.openedition.org/abstractairanica/40958 ; DOI : https://doi.org/10.4000/abstractairanica.40958

Ce document a été généré automatiquement le 3 octobre 2020.

Tous droits réservés 


\title{
Mawlānā Nūr al-Dīn 'Abd al-Raḥmān Jāmī. Tuhfat al-aḥrār. Éd. et commentaire Bìtā Nūrīyān
}

\author{
Anna Livia Beelaert
}

\section{RÉFÉRENCE}

Mawlānā Nūr al-Dīn 'Abd al-Raḥmān Jāmī. Tuhfat al-aḥrār. Éd. et commentaire Bītā

Nūrīyān, Eṣfahān, Entešārāt-e taḥīiāàt-e naẓarī, 1387/[2008], 226 p.

1 Ce troisième matnawī des Haft Awrang que Jāmī a composé en émulation de la Hamse de Nezāāī est édité ici à base du manuscrit autographe de Saint-Pétersbourg, daté de 890/1485, trois manuscrits du IX $\mathrm{IXV}^{\mathrm{e}}$ s. conservés à Téhéran, et l'édition de Mudarrese Gīlānī (Téhéran 1337/1958). Selon Nūrīyān cette nouvelle édition est justifiée par les nombreuses imperfections de cette dernière. Chose étonnante: elle n'a pas utilisé l'édition de Ḥusayn Ahmad Tarbīyat (Moscou 1984, rééditée à Téhéran en 1378/1999; Abs. Ir. 22, c.r. $n^{\circ} 481$ ), à base du même autographe et de quelques autres manuscrits qui se trouvent dans l'ex-URSS, bien que cette réédition figure dans la bibliographie ainsi que dans la préface. Nūrīyān (p. 9-10) argumente que la collation des manuscrits qui a pris une dizaine d'années a mis à jour de nombreuses différences. Toutefois, tous les exemples de leçons erronées dans l'édition de Mudarres-e Gīlānī énumérées p. 29-33 et corrigées ici s'avèrent l'avoir été déjà dans l'édition de Tarbìyat, une confrontation avec celle-ci eût été bien plus utile.

Le commentaire (p.137-202 ; explication de mots, figures de style etc.) est d'un usage peu pratique, se référant à une numérotation des vers qui manque dans le texte.

Le livre est pourvu de quelques index (avec par exemple les références au Coran et aux hadīts), qui manquaient dans les éditions précédentes. 


\section{AUTEURS}

ANNA LIVIA BEELAERT

Université libre de Bruxelles 